University of Warmia and Mazury in Olsztyn,

Poland

michal.pietkiewicz@uwm.edu.pl

MALWINA TREDER

University of Warmia and Mazury in Olsztyn,

Poland

maltreder@gmail.com

\title{
CYBERSTALKING IN SOCIAL MEDiA - POLISH VIEW
}

\begin{abstract}
This paper was inspired by the necessity to communicate the dire effects of classic stalking and to outline the penalties enforceable under Art. 190a $\$ 1$ of the Polish Criminal Code. The specifics of cyberstalking are then enumerated with emphasis on quoted social site internal rules instituted for the prevention of personal harassment.
\end{abstract}

KEYWORDS: cyberstalking, stalking, social media, cybercrimes.

\section{STALKING - GENERAL ISSUES}

Stalking is generally described as the repeated behavior, even up to several dozen times a day, which is unwanted by the victim and causes a sense of danger and strong fear. This can include efforts to make contact directly "face to face" or indirectly on the Internet (Tomaszek 2012, p. 138). The Polish Criminal Code (c.c) currently penalizes stalking under one legal norm, without distinction between classical stalking and cyberstalking. Article 190a \$1 c.c states: “Anyone who, through the persistent harassment of another person or another person's next of kin, creates a justified sense of danger or significantly violates the person's privacy, is subject to imprisonment for up to three years" (Ustawa z dnia 6 czerwca 1997 r. Kodeks karny - t.j. Dz. U. z 2016 r. poz. 1137 z późn. zm.).

The only qualified form of this crime is indicated in Art.190a \$3 c.c. which increases penalties if the perpetrator's actions result in a victim's suicide 
attempt. The legislator did not increase the penalty for acts created in mass media in similar manner to those increased for slander (Art. $212 \$ 2$ c.c.) and insult (Art. $216 \$ 2$ c.c.).

Article 190a was added to the Criminal Code in 2011, and the draft justification of the Act in Print 3553 which penalizes stalking was dictated by the need to create a protective instrument for persons victimized by negative social interaction, such as stalking (Ustawa $\mathrm{z}$ dnia 25 lutego 2011 r. o zmianie ustawy - Kodeks karny - Dz. U. Nr 72, poz. 381). The Polish Ministry of Justice initiated 2009 studies to determine the scale of this type of behavior throughout the country; with $9.9 \%$ of respondents indicating that they were victims of stalking, and unsolicited e-mails were one of the major method of persistent harassment. (Uzasadnienie projektu zmiany ustawy - Kodeks karny, druk 3553, Ustawa z dnia 25 lutego 2011 r. o zmianie ustawy - Kodeks karny - Dz. U. Nr 72, poz. 381).

Before the June $6^{\text {th }} 2011$ amendment came into force, the law enforcement agencies had very limited ability to combat stalking with available regulations because these failed to ensure full protection for victims. Effective action was only possible when the perpetrator's actions fell within the following prescribed criminal acts; punishable threats (Art. 190 c.c.), violation of physical integrity (Article 217 c.c.) and malicious harassment (Art. 107 Code of Petty Offences); (Zygmunt, 2013, p. 407).

The most important statutory features of the June 6th 2011 amendment recognize stalking as a multifarious crime where harassment involves persecution by repetitive actions which anguish, torment, bully or disturb the victim. The penalized behavior can consist of activities assessed in a single manner as legal actions. Sending unsolicited e-mails are an example here (Hypś, 2012, p. 858).

The behavior persists if it is continued despite the clear objection of the injured party (Zoll, 2013, p. 606), and persistence is judged by the following combined elements: the perpetrator's behavior should be subjectively analyzed with the mental attitude of tenacity, the will to "stand on its own" and the action is consistent despite adversity. These actions should then be considered over a period of time, with the certainty that they do not constitute a single behavior (Kosonoga 2015, p. 1089). 
The motives of criminal behavior can be various and may include: jealousy, vengeance, obsessions and delusions, or the desire to exercise control over a particular person (Siwicki, 2013, p. 284). In the criminological sense of meaning, various motives of the perpetrator's behavior are observed. It is noted that they may be in the form of bad intentions and actions to harm the victim, but also that they may result from disturbed or indeed legally indifferent intentions. These actions can be taken against the victim, her family or relatives. Sometimes, they can be starting point for more serious criminal behavior towards the victim (Królikowski, Sakowicz, 2017, p. 615).

Persistent harassment can be very effective. The statutory characteristics of this offence are creation of a justified sense of danger or significant violation of personal privacy. While the sense of danger must be perceived subjectively by the victim, it must also be justified from an objective view-point (Kłączyńska, 2014 , p. 470). The sense of threat also depends on the individual recipient's personality because behavioral reactions differ in different subjects. Some stalking victims experience anxiety and change their relationships with others or even decide to seek psychological help. Others, however, due to their strong psyche or appropriate personal protection do not experience the ill-effects of this behavior to such a great extent.

Research carried out in various countries also shows how serious may be the consequences of harassment for the aggrieved party. For example German research shows, that $90 \%$ of victims change their behavior in relationships with other people, over $50 \%$ of victims change jobs or stop working, 39\% of victims change their place of residence, $83 \%$ of victims show elevated levels of anxiety, 25\% of victims have serious suicidal thoughts and 25\% suffer from various post-traumatic disorders. In a British survey results showed that 59\% of victims began to avoid certain places and people, 35\% are less likely to go out from home, and $42 \%$ have taken action to improve their own safety and in $77 \%$ victims were diagnosed of mental disorders - mainly depression and anxiety (Woźniakowska-Fajst, 2009, pp. 7-10).

Here, M. Mozgawa, states that although there may be absence of threat to the aggrieved party, persistent harassment should certainly be penalized even if it only involves the need for significant and uncomfortable changes in the victim's private life (Mozgawa 2014, s. 472). 
Privacy violation entails perpetrator acts against the will of the aggrieved party in public, private or family life. This can affect personal matters, public disclosure of private life or insinuation that the victim is "bad". This behavior includes breach of correspondence and domestic trespass (Hypś, 2015, p. 952); with the latter act penalized by Art. 193 c.c. and possible aggregated penalty under Art. 190a \$1 c.c. (Zoll, 2013, p. 610).

It is impossible to catalog behaviors which fulfill the statutory features of the crime penalized by Art. 190a $\$ 1$ c.c., especially because of the increasing possibilities from technological development. The classic form of stalking often consists of repeated phone calls, including 'dead line calls', victim tracking, constant prowling of the victim's home or work, burglaries from house or car and sending unsolicited letters, gifts and e-mails (Michalska - Warias, 2013, p. 498).

As it was mentioned above, the acts constituting a crime of stalking were not included in the codex catalog and it can take on various forms. The negative consequence of this is the unconsciousness of the victim or if the acts of violence used against him or her by the persecutor are legally sanctioned or not. The absence of an enumerative catalog of these deeds, however, also has a positive aspect, because it allows for a flexible classification of each individual case (Leszczuk-Fiedziukiewicz' 2017, p. 128).

\section{THE ESSENCE OF CYBERSTALKING}

No definition of cyberstalking appears in Polish legal acts with statutory rank, therefore it is necessary to refer to literature reviews. Cyberstalking is defined as: "persistent and unprovoked behavior, involving multiple threats and behaviors that plague the victim, despite his or her suffering and requests for cessation, using communication and information tools, resulting in the victim's fear for safety" (Groth, 2010, s. 87).

Stalking and cyberstalking are somewhat similar, as the perpetrators act to threaten and control their victims in both instances. While media coverage and anecdotal evidence identify females as most often affected by the classic stalking, the cyberstalking is 'open-slather' - anyone can target anyone. Cyberstalking covers all Internet activities with e-mail and other electronic communication intimidating the victim (Treder, 2016, p. 45). 
Examples of this behavior include: electronic messages containing threats or obscene elements, spamming, chat-room harassment, monitoring the victim's network and placing messages and posts on social media (Shimizu, 2013, p. 117). Technologically expert perpetrators now use options including tracking the geographic location of their victim via GPS, spyware and chips tracing cell phones. These tools enable perpetrators to track their victim, and stalker network expertise intensifies the activity (King-Ries, 2011, p. 137).

One of the first cases of cyberstalking was reported in the United States in 1996. The victim was Jayne Hitchcock (Anderson, 2010, s. 19) who subsequently founded 'Working to Halt Online Abuse' in 1997. This organization combats internet harassment through cyber-danger education. Three forms of cyberstalking were then distinguished at the beginning of the 20th century: the e-mail, the Internet and the computer ([online] www. haltabuse.org).

The characteristics of the first form are obvious - victim harassment via e-mail. This was one of the most popular initial methods of cyberstalking. Internet harassment includes stalker activity in online communities and this proliferated when chat-rooms became more often used by platform stalkers. The last cyberstalking form involves the stalker taking control of the victim's computer and using the internet and gaps in operating systems (Ogilvie, 2000, p. 2-3).

United States prevention measures were introduced when the FBI published a 2003 study by a specialized investigation unit. While the computer was the main perpetration tool in this study, further research revealed that between 1996 and 2000 the crime of cyberstalking constituted $42.8 \%$ of all prohibited acts (Boone, 2011, p. 4).

Nowadays literature defines cyberstalking as a course of conduct directed at a specific person that involves repeated visual or physical proximity, non-consensual communication, or verbal, written or implied threats or a combination thereof, which would cause a reasonable person to fear. (Shimizu, 2013, p. 116). Nevertheless this study treats about the cyberstalking in conjunction with social media, therefore the next part of this study will narrow the subject 


\section{SOCIAL MEDIA AND CYBERSTALKING}

The Internet is constantly evolving as a network and therefore user preferences and the Internet communities are also changing. The discussion forums associating users with similar interests were initially so popular that they formed niche communities. These were then superseded by social media portals-internet websites whose primary function is interaction between users. This is opposed to the traditional portals where communication functions at the creator-user level. An important element of this type of website is the possibility of creating an individualized profile of the user who is responsible for identifying the actions of a given person within a given virtual community. The main purposes of this type of portal are: the free communication between users, the information flow and the publication of text, photos, music and movies (Grześkowiak, 2011, p. 359-360).

By 2008, portals such as: www.nasza-klasa.pl, fotka.pl and grono.net were ranked among the top Polish social networking sites (Małecka, Małecki, 2008, p. 6), but these are no longer in widespread use.

Reports assert that we are social. The document "Digital in 2017: Eastern Europe" shows that 39\% of Poles actively using social media in January 2017. This is an increase of $7 \%$ in compare to the previous year. The data for this period indicates the most popular social platforms, which are: Youtube, Facebook, Google+, Twitter, Instagram, Nasza Klasa, LinkedIn and Pinterest ([online]https://www.slideshare.net/wearesocialsg/digital-in-2017-easterneurope).In addition, the Digital in 2017 Global Overview reported that $73 \%$ of Polish users registered on the Facebook social network used it on a daily basis throughout January 2017. This result confirms that Poland is third on the global list of users - behind only Australia and Italy ([online]https:// www.slideshare.net/wearesocialsg/digital-in-2017-global- overview?utm source=slideshow02\&utm_medium $=$ ssemail\&utm_campaign $=$ share slideshow_loggedout).

It is not surprising that cyberstalking in social media is becoming more and more popular. The Internet and social networks are most attractive to stalkers who would not dare act in this manner in the real world. The structure and functioning of social networking websites such as Facebook facilitates stalkers' activities and even encourage punishable offences (Dreßing, Bailer, 
Anders, Wagner, 2014, p. 61). Current access to the Internet is so easy and popular that many people are basically on-line all the time and users intent on cyberstalking are aware that this is often more hurtful and harmful to the victim than classic stalking and also that the current risk of legal retribution is limited. While the recipient may already experience psychological trauma, the cyberstalking can easily escalate to harassment outside virtual communities through persistent telephone calls, vandalism and even direct physical attack (Chiks, 2008, s. 17).

The creators of social networking sites have already recognized the problems involved in stalking and other forms of harassment. They have established the following rules for users:

Point 3.3 in Facebook regulations warns users: "You will not bully, intimidate, or harass any user." ([online] https://www.facebook.com/legal/ terms/update). The "community standards" developed by Facebook also indicate that it does not tolerate harassment or persecution. This type of behavior includes: "Repeatedly targeting other people with unwanted friend requests or messages" ([online] https://www.facebook.com/ communitystandards\#bullying-and-harassment). The creators of this social networking site also increase preventative measures by creating the "Bullying Prevention Hub" in conjunction with the Yale Center for Emotional Intelligence. Facebook thereby provides a subpage of short guides in the form of PDF files with separate information and instructions for teenagers, parents and teachers. This lists the behaviors which qualify as harassment, propose action to counter stalking while logged-on to their web-site and remedial actions available outside the internet ([online] https://www.facebook.com/ safety/bullying). Although, the Facebook creators have declared cooperation with law enforcement agencies, the Polish version of the site only provides information on cooperation under US law. Requests for information can also be sent via e-mail to addresses in the US and Ireland or using the online law enforcement application system. This latter assistance, however, is only available in the English language ([online] https://www.facebook.com/safety/ groups/law/guidelines/).

A similar harassment prevention policy is used on the Instagram social networking site which is, in fact, a Facebook platform. Point 6 in the "Basic 
Terms" section of its regulations covers prohibition of harassment, where the user: "must not defame, stalk, bully, abuse, harass, threaten, impersonate or intimidate people or entities and you must not post private or confidential information via the Service, including, without limitation, your or any other person's credit card information, social security or alternate national identity numbers, non-public phone numbers or non-public email addresses" ([online] https://help.instagram.com/478745558852511).

While Snapchat is a mobile application and not a typical social networking site, it has more general guidelines: "We don't tolerate bullying or harassment on Snapchat.", "Don't Snap with the intention of making someone feel bad. If someone blocks you, it's not okay to contact them from another account" ([online] https://support.snapchat.com/en-US/a/guidelines).

The Twitter Rules also instruct: "You may not engage in the targeted harassment of someone, or incite other people to do so. We consider abusive behavior an attempt to harass, intimidate or silence someone else's voice" ([online] https://support.twitter.com/articles/20170455).

The Youtube Policy Center states; "We want you to use YouTube without fear of being subjected to malicious harassment. In cases where harassment crosses the line into a malicious attack it can be reported and will be removed". They then continue that harassment includes: "Abusive videos, comments, messages", "Revealing someone's personal information, including sensitive personally identifiable information such as social security numbers, passport numbers, or bank account numbers", "Maliciously recording someone without their consent", "Deliberately posting content in order to humiliate someone", "Making hurtful and negative comments/videos about another person", "Unwanted sexualization which encompasses sexual harassment or sexual bullying in any form" and finally "Incitement to harass other users or creators" ([online]https://support.google.com/youtube/answer/2802268?visit_id=1636269223109255275-3410331201\&rd=1).

\section{CONCLUSiON}

Cyberstalking is has already been prevalent and certainly expected to proliferate. Moreover, the social media is the obvious tool to facilitate stalker crime because the current trend of sharing so much user's information 
enables potential perpetrators to obtain extra data through specialized spyware. An example here is that the once one popular social service 'naszaklasa.pl allowed "friends" to get information on birth-date, age, education status, workplace, phone number, e-mail address, marital status and family connections. Browsing a profile provided knowledge of user's photos and comments, dates and times of entries and the most common times of the Internet connection, and hence, the knowledge if the user communicates during working-hours.

One of the greatest dangers is that users, especially youth, crave to increase their attractiveness on the web and they add people whom they have never met in the real world to their list of "friends" on social networks. Some of these friends may have created an account with fake data. Users then lose control over privacy and safety, especially if they advertise future events they intend to patronize on the Facebook wall, thus disclosing their exact location. This behavior simplifies work for potential stalkers who can obtain a vast array of information on potential victims without leaving home. Although, the social networks include tools to limit the visibility of individual information, not all users are aware of this protection or wish to use it. Further, there are too many users who have no idea of the risks and consequences of disclosing such information about themselves on the web.

The communication format of some social networking sites can facilitate or hinder cyberstalking. Snapchat, for example, provides an operation based on sending private messages between users and this communication disappears after a few seconds. While this can offer protection, it can also create difficulty in establishing that a crime has been committed. Moreover, sites "hiding" perpetrators under false data hinder both identification and initiation of criminal proceedings.

Although there are no hard statistics, as more people take advantage of the Internet and other telecommunications technologies, cyberstalking will become more prevalent and dangerous (Merschman, 2001, p. 255,276). As authors tried to reach for necessary data, the most relevant became Statistics from the Polish Ministry of Justice that confirm that valid convictions for harassment under Art. 190a \$1 c.c. are still rising, despite no differentiation indicated between stalking and cyberstalking ([online] https://isws.ms.gov. 
$\mathrm{pl} / \mathrm{pl} /$ baza-statystyczna/opracowania-wieloletnie). The increased popularity of social media ensures that cyberstalking will not cease. Moreover, the Internet use identifies with the myth of impunity because young users, in particular, treat this virtual world as an alternative reality which cannot affect their real life (Pietkiewicz, 2015, p. 157-169). All networking site policies which condemn harassment should be evaluated positively and although sanctions emanating from these portals can be painful, cyberstalking must be legally pursued. The most important protective measures include information campaigns which educate all factions of society on awareness of the Internet activities which constitute criminal activity.

\section{References:}

Anderson W. L. (2010). Cyber Stalking (Cyber Bullying) - Proof and Punishment. Insights to a Changing World Journal, 12, pp. 19. ISSN 1550-1574.

Boone J. (2011). Criminal Use of Social Media, Fairmont: National White Collar Crime Center.

Chiks W. (2008). Harassment through the Digital Medium A Cross-Jurisdictional Comparative Analysis on the Law on Cyberstalking, Journal of International Commercial Law and Technology, 3, pp. 17. ISSN 1901-8401 .

Dreßing H., Bailer J., Anders A., Wagner H., Gallas C. (2014) Cyberstalking in a large sample of social network users: prevalence, characteristics, and impact upon victims. Cyberpsychology, Behavior and Social Networking., 2 (17), pp. 61. ISSN 2152-2715.

Groth J. (2010). Cyberstalking - perspektywa psychologiczna. Forum oświatowe, 2, pp. 87. ISSN 0867-0323.

Grześkowiak U. M. (2011). Portale społecznościowe - wybrane aspekty. Zeszyty Naukowe Uniwersytetu Szczecińskiego. Studia Informatica, 28, pp. 359-360. ISSN 0867-1753.

Hypś S. (2012) w: Grześkowiak A., Wiak K. (ed.) Kodeks karny. Komentarz (pp. 858) Warszawa: Wydawnictwo CH Beck. ISBN 9788325536091.

Hypś S. (2015) w: Grześkowiak A., Wiak K. (ed.), Kodeks karny. Komentarz (pp. 952). Warszawa: Wydawnictwo CH Beck. ISBN 9788325536091

King-Ries A. (2011) Teens, technology and cyberstalking: the domestic violencewave of the future, Texas Journal of Women and the Law, 20, pp.137. ISSN 1058-5427.

Kłączyńska N. (2014) w: Giezek J. (ed.). Kodeks karny. Część szczególna. Komentarz, (pp. 470). Warszawa. ISBN 9788326441998. 
Kosonoga J. (2015) w: Stefański R. A. (ed.) Kodeks karny. Komentarz (pp.1089). Warszawa: Wydawnictwo CH Beck. ISBN 9788325576394.

Leszczuk-Fiedziukiewicz A. (2017). Między cyberprzemocą a „hejtem”. Kampanie społeczne związane $\mathrm{z}$ agresją $\mathrm{w}$ Internecie: w: Pływaczewski E., JurgielewiczDelegacz E., Dajnowicz-Piesiecka D. (ed.) Współczesna przestępczość i patologie społeczne z perspektywy interdyscyplinarnych badań kryminologicznych (pp. 128). Warszawa: Wydawnictwo CH Beck. ISBN 9788325590062.

Małecka M., Małecki B. (2008). Analiza rozwoju portali społecznościowych w Internecie (pp.6). Warszawa: Polska Agencja Rozwoju Przedsiębiorczości (PARP).

Merschman J. C. (2001). The Dark Side of the Web: Cyberstalking and the Need for Contemporary Legislation. Harvard Women's Law Journal, 24, pp. 255,276. ISSN 0270-1456.

Michalska-Warias (2013) w: Bojarski T. (ed.), Kodeks karny. Komentarz (pp. 498). Warszawa: Wolters Kluwer Polska. ISBN 9788327802125.

Mozgawa M. (2014) w: Mozgawa M. (ed.), Kodeks karny. Komentarz (pp. 472), Warszawa: Wydawnictwo Wolters Kluwer Polska. ISBN 9788326433757.

Tomaszek K. (2012) Stalker - psychologiczna charakterystyka sprawców przestępstw „uporczywego nękania”. w: Gorbaniuk O., Kostrubiec-Wojtachnio B., Musiał D., Wiechetek M. (ed.) Studia z Psychologii w KUL, tom 18 (pp.138) Lublin: Wydawnictwo KUL. ISBN 9788377027264.

Ogilvie E. (2000) Stalking and Cyberstalking, Australian Institute of Criminology. Trends \& Issues in Crime and Criminal Justice, 166, pp. 2-3. ISSN 0817-8542.

Pietkiewicz M. (2013). Wobec poczucia bezkarności. Specyfika wybranych przestępstw popetnianych za pośrednictwem internetu. w: Zimny J. (ed.), Praworzadność. Wczoraj-dziś-jutro (pp. 157-169). Stalowa Wola: Katolicki Uniwersytet Lubelski Jana Pawła II w Lublinie. ISBN 9788363835316.

Treder M. (2016) w: Opalska A., Treder M., Tymieniecka A. (ed.), Social media. Analiza prawnokarna i kryminologiczna. Zagadnienia wybrane, Szczecin: Wydawnictwo Volumina.pl. ISBN 9788378673712.

Shimizu A. (2013). Recent Developments: Domestic Violence in the Digital Age: Towards the Creation of a Comprehensive Cyberstalking Statute, "Berkeley Journal of Gender, Law \& Justice", 28, pp. 116-117. ISSN 1933-1045.

Zygmunt Ł. (2013) w: Trybus M., Wilk T. (ed.) Przestępstwa rzadko podejmowane przez organy ścigania. Aspekty kryminalistyczne, materialnoprawne i procesowe (pp.407) Rzeszów: Wydawnictwo Uniwersytetu Rzeszowskiego. ISBN 9788373389403. 
Zoll A. (2013) w: Zoll A. (ed.) Kodeks karny. Część szczególna. Komentarz LEX. Tom II. Komentarz do art. 117-227 k.k. (pp.498-606) Warszawa: Wydawnictwo Wolters Kluwer Polska. ISBN 9788326440816.

\section{Legal acts}

Ustawa z dnia 6 czerwca 1997 r. Kodeks karny. (t.j. Dz. U. z 2016 r. poz. 1137 z późn. zm.). Ustawa z dnia 25 lutego 2011 r. o zmianie ustawy - Kodeks karny. (Dz. U. Nr 72, poz. 381).

Uzasadnienie projektu zmiany ustawy - Kodeks karny, druk 3553, Ustawa z dnia 25 lutego 2011 r. o zmianie ustawy - Kodeks karny. (Dz. U. Nr 72, poz. 381)

\section{Online}

https://www.facebook.com/communitystandards\#bullying-and-harassment https://www.facebook.com/legal/terms/update https://www.facebook.com/safety/bullying https://www.facebook.com/safety/groups/law/guidelines https://www.haltabuse.org https://help.instagram.com/478745558852511 https://isws.ms.gov.pl/pl/baza-statystyczna/opracowania-wieloletnie https://www.slideshare.net/wearesocialsg/digital-in-2017-eastern-europe https://www.slideshare.net/wearesocialsg/digital-in-2017-global- overview?utm_ source=slideshow02\&utm_medium=ssemail\&utm_campaign=share_slideshow_ loggedout

https://support.google.com/youtube/answer/2802268?visit_id=1636269223109255275-3410331201\&rd=1

https://support.snapchat.com/en-US/a/guidelines https://support.twitter.com/articles/20170455 